\title{
EFFECT OF SUGARCANE BAGASSE ASH ON STRENGTH PROPERTIES OF CONCRETE
}

\author{
K. Lakshmi Priya ${ }^{1}$, R. Ragupathy ${ }^{2}$ \\ ${ }^{1}$ M.E., Structural Engineering, Department of Civil Engineering, PSG College of Technology, Coimbatore, India \\ ${ }^{2}$ Associate Professor, Department of Civil Engineering, PSG College of Technology, Coimbatore, India
}

\begin{abstract}
The present study focuses on the utilization of Sugarcane Bagasse Ash as replacement material for cement in concrete production. Sugarcane Bagasse ash contains high amorphous silica content and aluminium ion. For experimental investigations, Sugarcane bagasse ash and its chemical properties are obtained from KCP sugar factory, Andhra Pradesh. Ordinary Portland cement was partly replaced by sugarcane bagasse ash in the ratio of $0 \%, 5 \%, 10 \%, 15 \%, 20 \%$ and 25\% by weight and the influence of Sugarcane bagasse ash as a partial replacement material has been examined on fresh concrete tests by Compaction factor test and Slump cone test as well as on hardened concrete with tests for Compressive strength, Split tensile strength, Flexural strength and Modulus of Elasticity. The results indicate that inclusion of Sugarcane Bagasse Ash in concrete up to 20\% level significantly enhanced the strength of concrete. The highest strength was obtained at 10\% Sugarcane bagasse ash replacement level.
\end{abstract}

Keywords: Sugarcane Bagasse Ash, By-Product, Amorphous Silica and Strength

\section{INTRODUCTION}

Regular concrete is often produced with four components namely, a) cement and b) water, together acting as binder, c) crushed stone and d) natural sand and sometimes other cementitious and chemical admixtures. The aggregates are relatively inert filler materials, which occupy $70 \%$ to $80 \%$ of the concrete and can therefore be expected to have influence on its properties. The proportion of these components, the paste and the aggregate is controlled by the strength, durability of the desired concrete, the workability of the fresh concrete and the cost of the concrete.

Agricultural wastes like wheat straw ash, rice husk ash, hazel nutshell and Sugar Cane Bagasse Ash (SCBA) contribute for the development of concrete by acting as pozzolanic materials [4]. Presently, the study is to utilize SCBA, the waste from sugar industry. When this waste is burned at around $600-800^{\circ} \mathrm{C}$, it produces ash containing large amount of amorphous silica having pozzolanic properties. So, it is conceivable to use SCBA as cement replacement material to improve concrete properties like workability and strength. Utilization of different cementitious materials along with SCBA for the production of SCBA blended cements confers to get sustainable concrete. Tremendous quantities of SCBA are obtained as by-product from combustion in sugar industries; Therefore, SCBA is suitable supplementary cementitious material for use in concrete. Ontogeny of population, growing urbanization, and the mounting standard of living due to technological inventions are the reason for an increase in the quantity and variety of solid wastes generated by mining, domestic industrial and agricultural activities [7]. Annually, Asia alone produces 4.4 billion tonnes of solid waste [9]. The second largest producer of SCBA is India $(44,000$ tonnes/day) [1].
SCBA mainly contains reactive silica and can be used as pozzolanic material in concrete. The main components of raw bagasse are silica (60-75\%), $\mathrm{K}_{2} \mathrm{O}, \mathrm{CaO}$ and other minor oxides including $\mathrm{Al}_{2} \mathrm{O}_{3}, \mathrm{Fe}_{2} \mathrm{O}_{3}$, and $\mathrm{SO}_{3}[3,5,8]$. Low specific gravity (1.8-2.1) of raw bagasse ash may be due to of large amount of lightweight unburnt particles [4, 8]. The pozzolanic activity of SCBA mainly depends on its particle size and fineness $[2,4]$.

This paper investigates the impact of SCBA in concrete by partially replacing SCBA with cement in the ratio of $0 \%$, $5 \%, 10 \%, 15 \%, 20 \%$ and $25 \%$ by weight for M25 grade of concrete. The experimental study examines the slump of the fresh concrete, compaction factor, compressive strength, split tensile strength, flexural strength, and modulus of elasticity.

\section{MATERIAL DETAILS}

\subsection{Cement}

Ordinary Portland Cement (OPC) of 53 grade having specific gravity 3.14 and fineness $1 \%$ is used. The Standard consistency of cement is $30.5 \%$. The initial and final setting times are 90 minutes and 162 minutes respectively.

\subsection{Sugarcane Bagasse Ash}

The SCBA used for this investigation was obtained from KCP Sugar factory, Vuyyur, located in Krishna district, Andhra Pradesh. SCBA contains approximately 25\% of hemicellulose, $25 \%$ of lignin and $50 \%$ of cellulose. Each tonne of sugarcane generates approximately $26 \%$ of bagasse (at $50 \%$ moisture content) and $0.62 \%$ of residual ash. The 
residue after combustion gives a chemical composition dominated by silicon dioxide [10]. The Specific gravity of SCBA was found to be 2.17 . Chemical properties of SCBA are shown in Table -1 .

Table -1: Chemical Properties of SCBA

\begin{tabular}{|c|c|c|}
\hline Sl.no. & Component & Mass \% \\
\hline 1 & Silica $\left(\mathrm{SiO}_{2}\right)$ & 71.0 \\
\hline 2 & Alumina $\left(\mathrm{Al}_{2} \mathrm{O}_{3}\right)$ & 1.9 \\
\hline 3 & Ferric Oxide $\left(\mathrm{Fe}_{2} \mathrm{O}_{3}\right)$ & 7.8 \\
\hline 4 & Calcium Oxide $(\mathrm{CaO})$ & 3.4 \\
\hline 5 & Magnesium Oxide $(\mathrm{MgO})$ & 0.3 \\
\hline 6 & Potassium Oxide $\left(\mathrm{K}_{2} \mathrm{O}\right)$ & 8.2 \\
\hline 7 & Sodium Oxide $\left(\mathrm{Na}_{2} \mathrm{O}\right)$ & 3.4 \\
\hline 8 & Phosphorus Pentoxide $\left(\mathrm{P}_{2} \mathrm{O}_{5}\right)$ & - \\
\hline 9 & Manganese Oxide $(\mathrm{MnO})$ & 0.2 \\
\hline
\end{tabular}

\subsection{Fine Aggregate}

Regionally available river sand is used and it comes zone II as per Indian standards. The specific gravity of sand is 2.613. Fractions from $4.75 \mathrm{~mm}$ to $150 \mu$ are termed as fine aggregate, and the bulk density in loose state and rodded state are $1550.463 \mathrm{~kg} / \mathrm{m}^{3}$ and $1699.945 \mathrm{~kg} / \mathrm{m}^{3}$ respectively. The percentage of water absorption is $4.562 \%$.

Table -2: Sieve Analysis of Fine Aggregate

\begin{tabular}{|c|c|c|c|c|}
\hline $\begin{array}{c}\text { Sieve } \\
\text { size }\end{array}$ & $\begin{array}{c}\text { Weight } \\
\text { retained } \\
(\mathbf{k g})\end{array}$ & $\begin{array}{c}\text { Percent- } \\
\text { age of } \\
\text { weight } \\
\text { retained }\end{array}$ & $\begin{array}{c}\text { Cumul- } \\
\text { ativeper } \\
\text { cen-tage } \\
\text { retained }\end{array}$ & $\begin{array}{c}\text { Percen- } \\
\text { tage } \\
\text { finer }\end{array}$ \\
\hline $4.75 \mathrm{~mm}$ & 0.016 & 3.2 & 3.2 & 96.8 \\
\hline $2.36 \mathrm{~mm}$ & 0.026 & 5.2 & 8.4 & 91.6 \\
\hline $1.18 \mathrm{~mm}$ & 0.068 & 13.6 & 22 & 78 \\
\hline $600 \mu$ & 0.166 & 33.2 & 55.2 & 44.8 \\
\hline $300 \mu$ & 0.096 & 19.2 & 74.4 & 25.6 \\
\hline $150 \mu$ & 0.114 & 22.8 & 97.2 & 2.8 \\
\hline Pan & 0.014 & 2.8 & - & 0 \\
\hline
\end{tabular}

\subsection{Coarse Aggregate}

The crushed aggregates of $20 \mathrm{~mm}$ nominal size from the local source is used and its specific gravity is 2.31 . The bulk density in loose state and rodded state are $1778.618 \mathrm{~kg} / \mathrm{m}^{3}$ and $1907.981 \mathrm{~kg} / \mathrm{m}^{3}$ respectively. The percentage of water absorption is $0.217 \%$.

\subsection{Water}

The locally available potable water accepted for local construction as per IS: 456-2000 [17] was used in the experimental investigation.

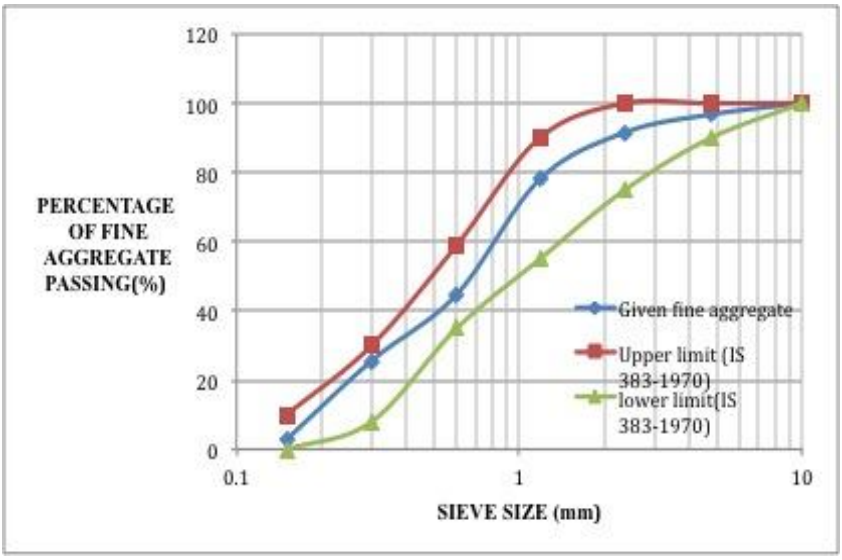

Chart -1: Particle Size Distribution of Fine Aggregate

Table -3: Sieve Analysis of Coarse Aggregate

\begin{tabular}{|c|c|c|c|c|}
\hline $\begin{array}{c}\text { SI. } \\
\text { no. }\end{array}$ & $\begin{array}{c}\text { Sieve } \\
\text { size }\end{array}$ & $\begin{array}{c}\text { Weight } \\
\text { retained } \\
\text { (kg) }\end{array}$ & $\begin{array}{c}\text { Percent- } \\
\text { age of } \\
\text { weight } \\
\text { retained }\end{array}$ & $\begin{array}{c}\text { Cumulative } \\
\text { percentage } \\
\text { retained }\end{array}$ \\
\hline 1 & $80 \mathrm{~mm}$ & 0 & 0 & 0 \\
\hline 2 & $40 \mathrm{~mm}$ & 0 & 0 & 0 \\
\hline 3 & $20 \mathrm{~mm}$ & 1.34 & 26.8 & 26.8 \\
\hline 4 & $10 \mathrm{~mm}$ & 3.66 & 73.2 & 100 \\
\hline 5 & $4.75 \mathrm{~mm}$ & 0 & 0 & 100 \\
\hline 6 & $2.36 \mathrm{~mm}$ & 0 & 0 & 100 \\
\hline 7 & $1.18 \mathrm{~mm}$ & 0 & 0 & 100 \\
\hline 8 & $600 \mu$ & 0 & 0 & 100 \\
\hline 9 & $300 \mu$ & 0 & 0 & 100 \\
\hline 10 & $150 \mu$ & 0 & 0 & 100 \\
\hline
\end{tabular}

\section{EXPERIMENTAL INVESTIGATION}

Totally 72 concrete specimens were cast, out of which, 18 specimens were cubes, of standard dimensions $150 \mathrm{~mm} * 150 \mathrm{~mm} * 150 \mathrm{~mm}$ and 18 were prisms with dimensions $400 \mathrm{~mm} * 100 \mathrm{~mm} * 150 \mathrm{~mm}$, were casted for compression test and flexural test respectively. Similarly, 36 cylinders of standard dimension $150 \mathrm{~mm} * 300 \mathrm{~mm}$ were cast for split tensile test and modulus of elasticity. Three specimens were cast for each percentage of replacement and were cured in the curing tank for 28 days and were tested.

\subsection{Mix Details}

The mix design of concrete was done as per IS 10262:2009 [21]. Totally six mixes were prepared; one of the mixes with no SCBA content is called the control mix. The remaining five mixes were prepared by replacing cement partially with SCBA at specified ratios for M25 grade of concrete. The mixes were entitled as M0 for control mix and M1 - M5 for concretes with 5\%, 10\%, 15\%, 20\% and 25\% SCBA respectively. The mix details are outlined in Table- 4 . 
Table - 4: Mix Details

\begin{tabular}{|c|c|c|c|c|c|c|}
\hline $\begin{array}{c}\text { Mix } \\
\text { designation }\end{array}$ & $\begin{array}{c}\text { Cement } \\
\left(\mathrm{kg} / \mathrm{m}^{3}\right)\end{array}$ & $\begin{array}{c}\text { Fine } \\
\text { aggregate } \\
3 \\
\left(\mathrm{~kg} / \mathbf{m}^{3}\right)\end{array}$ & $\begin{array}{c}\text { SCBA } \\
\left(\mathrm{kg} / \mathbf{m}^{3}\right)\end{array}$ & $\begin{array}{c}\text { Coarse } \\
\text { aggregate } \\
\left(\mathbf{k g} / \mathbf{m}^{3}\right)\end{array}$ & W/C ratio & $\begin{array}{c}\text { Water } \\
\left(\mathrm{kg} / \mathrm{m}^{3}\right)\end{array}$ \\
\hline M0 & 394.320 & 639.168 & 0 & 1192.680 & 0.50 & 197.160 \\
\hline M1 & 374.604 & 636.502 & 19.716 & 1187.705 & 0.50 & 197.160 \\
\hline M2 & 354.888 & 633.836 & 39.432 & 1182.730 & 0.50 & 197.160 \\
\hline M3 & 335.172 & 631.170 & 59.148 & 1177.755 & 0.50 & 197.160 \\
\hline M4 & 315.456 & 628.504 & 78.864 & 1172.780 & 0.50 & 197.160 \\
\hline M5 & 300 & 624.562 & 98.580 & 1165.425 & 0.50 & 197.160 \\
\hline
\end{tabular}

\subsection{Workability}

A good-quality concrete should have acceptable workability in the fresh condition and should develop sufficient strength. The workability of the freshly mixed concrete was determined using slump cone test and compaction factor test.

\subsection{Compressive Strength}

Compressive strength of SCBA blended concrete cubes was determined after 28 days curing and tested as per IS 516:1959 [18]. The rate of loading of compressive strength testing machine is 0.5 tonnes/sec.

\subsection{Split Tensile Strength}

Cylinders of size $150 \mathrm{~mm}$ in diameter and $300 \mathrm{~mm}$ in length were cast and cured for 28 days. Each split tensile strength result is the average of three specimens. The test was conducted in a compression testing machine as per the Indian code IS 516:1959[18] and the maximum load applied on the specimen at the failure was recorded and the strength was calculated by using appropriate equation.

\subsection{Flexural Strength}

Prism specimens that are cast and cured for 28 days were tested for maximum load. Flexural strength of concrete prism specimens containing various amount of bagasse ash was determined.

\subsection{Modulus of Elasticity}

Modulus of elasticity of cylinder specimens was determined using a compressometer. The Gauge length of compressometer is $200 \mathrm{~mm}$ and least count of dial gauge is $0.002 \mathrm{~mm}$.

\section{RESULTS AND DISCUSSIONS}

\subsection{Effect of SCBA on workability}

\subsubsection{Slump Cone Test}

Table - 5 shows the slump values for all the concrete mixes. Since the water content was constant in all six mixes, the effect of SCBA on workability of concrete can be better understood. As shown in Chart-2, the workability of concrete increases with the increase in the SCBA content. For control mix concrete, M0 the slump value was obtained as $70 \mathrm{~mm}$, whereas for $25 \%$, the slump was about $160 \mathrm{~mm}$. It means the addition of SCBA content reduces the water demand in concrete.

Table - 5: Workability

\begin{tabular}{|c|c|c|}
\hline \multirow{2}{*}{ SCBA } & \multicolumn{2}{|c|}{ Workability } \\
\cline { 2 - 3 } & Slump $(\mathbf{m m})$ & Compaction Factor \\
\hline 0 & 70 & 0.88 \\
\hline 5 & 85 & 0.91 \\
\hline 10 & 90 & 0.91 \\
\hline 15 & 100 & 0.93 \\
\hline 20 & 125 & 0.94 \\
\hline 25 & 160 & 0.96 \\
\hline
\end{tabular}

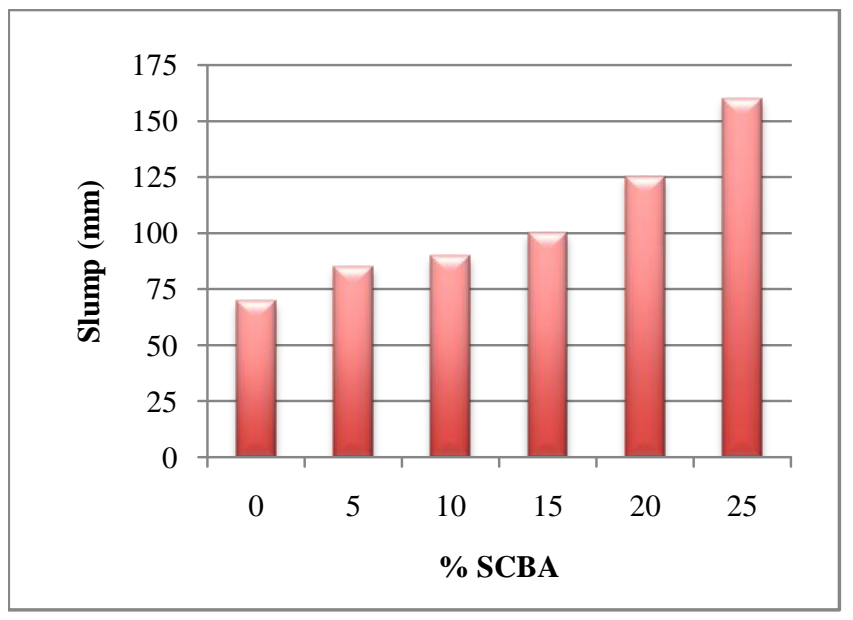

Chart -2: Variation of Slump

\subsubsection{Compaction Factor Test}

Chart-3 represents the influence of SCBA content on the compaction factor of all mixes at constant w/c ratio. The results indicate that unlike the M0 mix, other SCBA mixtures had high compaction factor values and acceptable workability.

\subsection{Compressive Strength}

Table- 6 indicates the average compressive strength of all six mixes determined at the age of 28 days. Four mixes containing $5 \%, 10 \%, 15 \%$ and $20 \%$, respectively SCBA showed higher compressive strength than M0 mix, whereas M5 mix indicated lesser compressive strength than the M0 
mix because quantity of amorphous silica present in the mixture is higher than the amount needed to react with calcium hydroxide produced during hydration reaction, therefore reducing the overall strength of specimen.

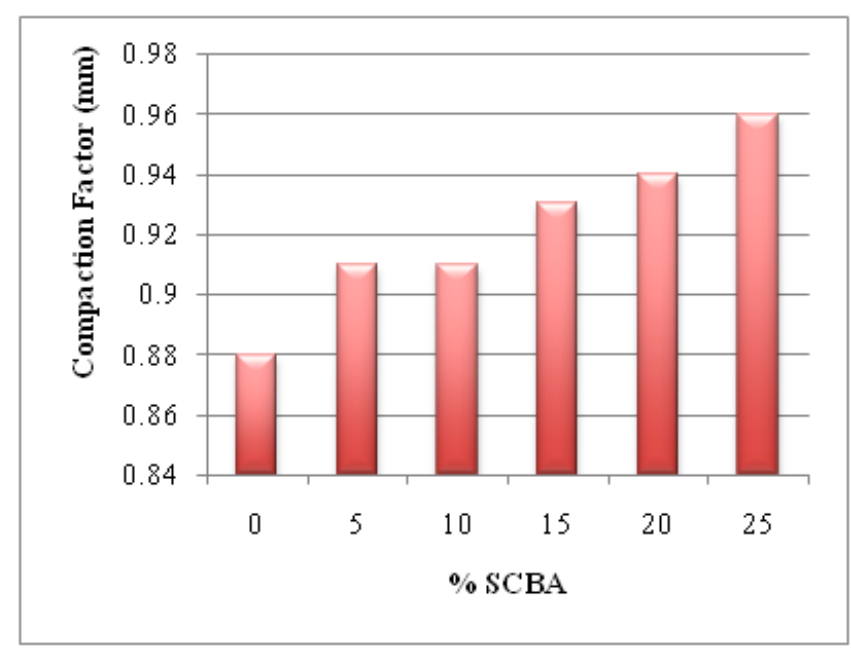

Chart -3: Variation of Compaction Factor

Table -5: Average Compressive Strength

\begin{tabular}{|c|c|c|}
\hline $\begin{array}{c}\text { Mix } \\
\text { Designation }\end{array}$ & \% SCBA & $\begin{array}{c}\text { Average } \\
\text { Compressive } \\
\text { Strength }\left(\mathbf{N} / \mathbf{m m}^{2}\right)\end{array}$ \\
\hline M0 & $0 \%$ & 33.281 \\
\hline M1 & $5 \%$ & 37.351 \\
\hline M2 & $10 \%$ & 38.077 \\
\hline M3 & $15 \%$ & 36.769 \\
\hline M4 & $20 \%$ & 35.752 \\
\hline M5 & $25 \%$ & 30.956 \\
\hline
\end{tabular}

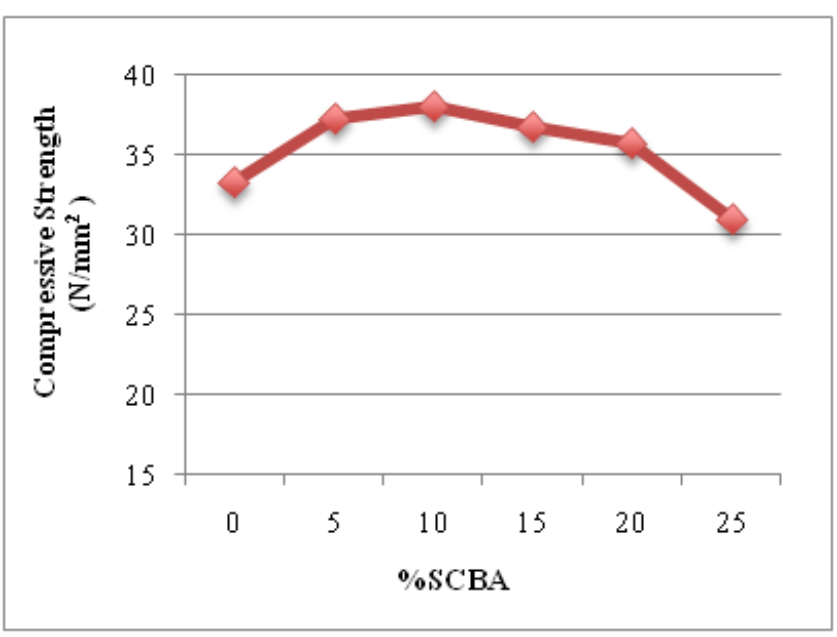

Chart -4: Variation of Compressive Strength

\subsection{Split Tensile Strength}

The split tensile strength of SCBA blended cement concrete is more than M0 concrete mix up to $20 \%$ replacement of cement with SCBA (M4), as shown in Chart-5. Further increase in the level of replacement to $25 \%$ lead to marginal reduction in split tensile strength of the concrete, probably due to the dilution effect.
Table -6: Average Split Tensile Strength

\begin{tabular}{|c|c|c|}
\hline $\begin{array}{c}\text { Mix } \\
\text { Designation }\end{array}$ & \% SCBA & $\begin{array}{c}\text { Average Split Tensile } \\
\left.\text { Strength (N/mm }{ }^{2}\right)\end{array}$ \\
\hline M0 & $0 \%$ & 2.102 \\
\hline M1 & $5 \%$ & 2.822 \\
\hline M2 & $10 \%$ & 3.077 \\
\hline M3 & $15 \%$ & 2.938 \\
\hline M4 & $20 \%$ & 2.683 \\
\hline M5 & $25 \%$ & 1.897 \\
\hline
\end{tabular}

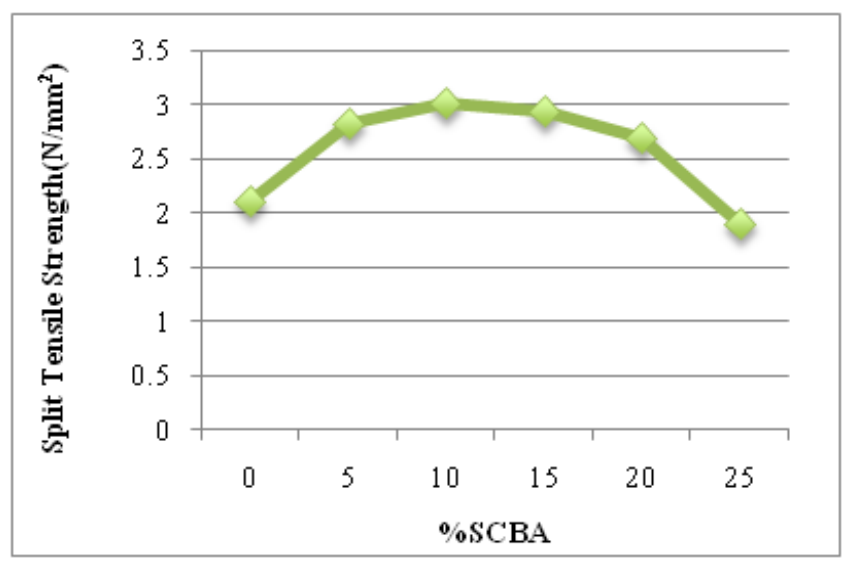

Chart -5: Variation of Split Tensile Strength

\subsection{Flexural Strength}

The results are given in the Table-7, and Chart- 6 indicates the variation in flexural strength for different cement replacements with SCBA, respect to control mix concrete. Highest flexural tensile strength is obtained for M2 mix containing $10 \%$ SCBA as partial replacement of cement and for M5 mix having 25\% SCBA strength it is less than that of control mix.

Table -7: Average Flexural Strength

\begin{tabular}{|c|c|c|}
\hline $\begin{array}{c}\text { Mix } \\
\text { Designation }\end{array}$ & \% SCBA & $\begin{array}{c}\text { Average Flexural } \\
\text { Strength (N/mm }\end{array}$ \\
\hline M0 & $0 \%$ & 6.065 \\
\hline M1 & $5 \%$ & 6.684 \\
\hline M2 & $10 \%$ & 6.821 \\
\hline M3 & $15 \%$ & 6.718 \\
\hline M4 & $20 \%$ & 6.386 \\
\hline M5 & $25 \%$ & 5.915 \\
\hline
\end{tabular}




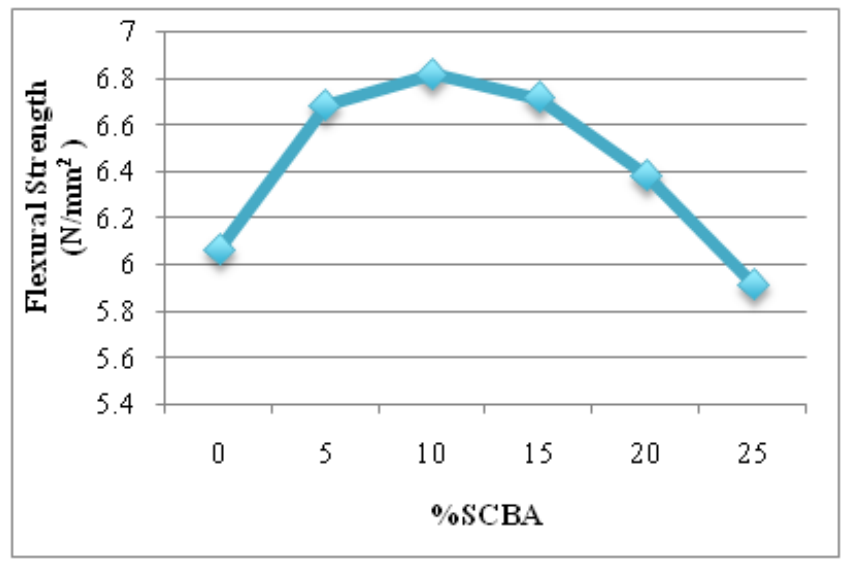

Chart -6: Variation of Flexural Strength

\subsection{Modulus of Elasticity}

Variation in Modulus of elasticity for different replacement levels is shown in Chart-7.

Table -8: Average Modulus of Elasticity

\begin{tabular}{|c|c|c|}
\hline Mix Designation & $\%$ SCBA & $\begin{array}{l}\text { Modulus of Elasticity } \\
\quad * 10^{4}\left(\mathrm{~N} / \mathrm{mm}^{2}\right)\end{array}$ \\
\hline M0 & $0 \%$ & 4.72 \\
\hline M1 & $5 \%$ & 5.02 \\
\hline M2 & $10 \%$ & 5.12 \\
\hline M3 & $15 \%$ & 5.07 \\
\hline M4 & $20 \%$ & 4.86 \\
\hline M5 & $25 \%$ & 4.66 \\
\hline
\end{tabular}

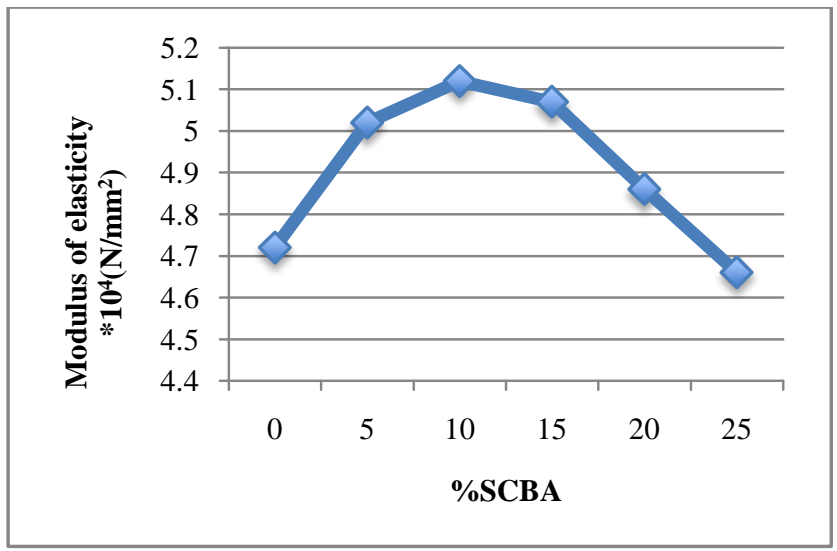

Chart -7: Variation of Modulus of Elasticity

The reasons for increase in strength up to $20 \%$ cement replacement of SCBA may be due to silica content, amorphous phase, fineness, specific surface area, degree of reactivity of SCBA and pozzolanic reaction between calcium hydroxide and reactive silica in SCBA in the alkaline environment as reported by previous works [2, 3, 6, 7]. At $25 \%$ SCBA, the strength decreases to a lesser value than that of control specimens. Therefore, 20\% SCBA blended concrete seems to be the optimal limit.

\section{CONCLUSIONS}

From the present analysis, I've come to the following conclusion. Up to $20 \%$ of OPC can be replaced optimally with well-burnt SCBA without any contrary effect on the desirable properties of concrete.

- Partial replacement of cement by SCBA boosts workability of fresh concrete; therefore use of super plasticizer is not essential.

- The results showed that, the concrete with $10 \%$ SCBA replacement after 28 days of curing, showed maximum strength when compared to concrete with other percentage replacement mixes.

- As the flexural tensile strength of SCBA concrete is more it can be used in slabs, beams etc., where higher flexural tensile strength is required.

- In the economic point of view, the cement replaced by SCBA saves money

- Since bagasse ash is a by-product material, its use as a cement replacing material reduces the levels of $\mathrm{CO}_{2}$ emission by the cement industry. In addition its use resolves the disposal problems associated with it in the sugar industries and thus keeping the environment free from pollution.

\section{FUTURE WORKS}

- The effect of different percentage replacement of cement by SCBA on the properties of the high strength concrete (M35, M40, M45 etc.,) is to be studied.

- Other properties of concrete like heat resistance and shear should be studied. It can also be studied in selfcompaction of concrete.

- Durability aspects of SCBA should be studied.

- The behavior of structural elements such as beams, columns and slabs made with sugarcane bagasse ash concrete should also be investigated.

\section{REFERENCES}

[1] A. Bahurudeen and M. Santhanam, "Sugarcane bagasse ash - An alternative supplementary cementitious material", Proc., International Conference on Advances in Civil Engineering and Chemistry of Innovative Materials, SRM University, Chennai, India, pp. 837842, 2014.

[2] Andrade, "Calculation of chloride diffusion coefficients in concrete from ionic migration measurements", Cement and Concrete Research, Vol. 23, Issue 3, pp. 724-742, 1993.

[3] Cordeiro, E. Vazquez, Ch.F. Hendricks and G.M.T. Janssen, "Influence of mechanical grinding on the pozzolanic activity of residual sugarcane bagasse ash", Proc., International RILEM conference on the use of recycled materials in building structures, 2004.

[4] G.C. Cordeiro, R.D. Filho, L.M. Tavares and E.M. Fairbairn, "Effect of calcination temperature on the pozzolanic activity of sugar cane bagasse ash", Construction and Building Materials,Vol. 23, Issue 10, pp. 3301-3303, 2009a. 
[5] G.C. Cordeiro, R.D. Filho, L.M. Tavares and E.M. Fairbairn, "Ultrafine grinding of sugar cane bagasse ash for application as pozzolanic admixture in concrete", Cement and Concrete Research, Vol. 39, Issue 2, pp. 110-115, 2009b.

[6] G.C. Cordeiro, R.D. Filho, L.M. Tavares and E.M. Fairbairn, "Ultrafine grinding of sugar cane bagasse ash for application as pozzolanic admixture in concrete", Cement and Concrete Research, Vol. 39, Issue 2, pp. 110-115, 2009b.

[7] J.L Escalante-Garcia and J.H Sharp, "The microstructure and mechanical properties of blended cements hydrated at various temperatures", Cement and Concrete Research, Vol. 31, Issue 5, pp. 695-702, 2001.

[8] J. Payá, J. Monzó, M.V. Borrachero, L. Díaz-Pinzón, L.M. Ordónez, "Sugar-cane bagasse ash (SCBA): studies on its properties for reusing in concrete production", Journal of chemical technology and biotechnology, Vol. 77, Issue 1, pp. 321-325, 2002.

[9] K. Ganesan, K. Rajagopal and K. Thangavel, "Evaluation of bagasse ash as supplementary cementitious material", Cement and Concrete Composites, Vol. 29, pp. 515-524, 2007.

[10] M. Frias, V. Ernesto and S. Holmer, "Brazilian sugar cane bagasse ashes from the cogeneration industry as active pozzolans for cement manufacture", Cement and Concrete Composites, Vol. 33, Issue 4, pp. 490-496, 2011.

[11] Nuntachai Chusilp, Chai Jaturapitakkul and Kraiwood Kiattikomol, "Utilization of bagasse ash as a pozzolanic material in concrete", Construction and Building Materials, Vol. 23, pp. 3352-3358, 24 July 2009.

[12] P. Asokan, M. Saxena and S.R. Asolekar, "Solid wastes generation in India and their recycling potential in building materials", Building and Environment,Vol. 42, Issue 6, pp. 2311-2320, 2007.

[13] R. Somna, C. Jaturapitakkul, P. Rattanachu and W. Chalee, "Effect of ground bagasse ash on mechanical and durability properties of recycled aggregate concrete", Materials and Design,Vol. 36, pp. 597-603, 2012.

[14]S. Yoshizawa and M. Tanaka, "Estimation and prediction of generation of solid waste in the world", Proc., Annual Meeting of Japan Society of Waste Management Experts, Japan Society of Material Cycles and Waste Management (JSMCWM), Tokyo, Japan, pp. 38-40, 2004.

[15] U. R. Kawade, V. R. Rathi and Vaishalid.Girge, "Effect of use of bagasse ash on strength of concrete", Construction and Building Materials, Vol. 2, Issue 7, pp. 2319-8753, July 2013.

[16] W. Aquino, D.A. Lange and J. Olek, "The influence of metakaolin and silica fume on the chemistry of alkalisilica reaction products", Cement and Concrete Composites, Vol. 23, Issue 6, pp. 485-493, 2001.

[17] IS 456: 2000, "Indian Standard, Plane and reinforced concrete - Code of practice", Bureau of Indian Standards, New Delhi.
[18] IS 516:1959, "Method of Tests for Strength of concrete", Bureau of Indian Standards, New Delhi, India.

[19] IS 383 -1970, "Specifications for Coarse and Fine Aggregates from Natural Sources for Concrete", Bureau of Indian Standards, New Delhi, India.

[20] IS 12269-1987," Specification for 53 Grade Ordinary Portland Cement", Bureau of Indian Standards, New Delhi, India.

[21] IS 10262 -2009 "IS Method of Mix Design", Bureau of Indian Standards, New Delhi, India. 